\title{
"The Effect of Synchronous Electronic Guidance on the Development of Teaching Competencies and the Reduction of Teaching Anxiety among the Teacher Students at the Faculty of Physical Education"
}

Dr. Abdallah Saied Mousa Mohamed Shreif ${ }^{(*)}$

\section{Introduction}

The world community is living in an era of human progress as a result of the amazing scientific and technological developments in computer science, networks and information and communication technologies, which have been reflected in educational systems and their need for diversity in the use of different technologies. Educational technology, In e-learning, because it provides an educational and interactive learning environment and rich information resources to mimic the traditional learning possibilities, and facilitate access to the sources of learning through interactive tools enables the user either staff member or any other learner to control over learning, interacting with the other members of the learning process $(8: 19)$

(*)Lecturer, School Sports Department, Faculty of Physical Education for men , Alexandria University

From the importance of developing teacher education programs in the technology revolution and meeting the needs of changing societies, Reem Nashad (2005) and Ibrahim Al Wakil (2002) note that the development of teacher education programs is ongoing and renewed as long as there is change in societies. Young people are the responsibility of the teacher in the first place, it requires that the programs and methods of preparing the teacher student for continuous development to raise efficiency and increase effectiveness in accordance with the change and development occurring in communities and imposed by the new variables should be taken into account in the preparation of young people. (26:37) (18:207) 
In the same context, teacher education programs have received considerable attention from educators to prepare a generation of teachers capable of bearing responsibility and positive participation, a generation that has the skills to deal with technological innovations capable of creativity and innovation. Mohammed Saad and others (2001) and Ismail Mohamed (2005) noted that the skills of self-learning and the use of modern technology has become a major goal in the preparation of the teacher's student and thus became an urgent demand for the nature of the age in which we live. Their teaching abilities and improved learning for the student. $(24: 33)(19: 12)$

Ahmed Gomaa (2012)and Abdul Hamid Bassiouni (2007) noted that education in particular is one of the most important areas of life which has been strongly affected and directly related to the development in information technology. $\mathrm{He}$ also pointed out that the methods of teaching and electronic training have multiplied and modern mechanisms have emerged which contribute to gaining experience. And skills as well as contribute to the means of transport without being bound by the limits of time and space (5:7) (1:43)

If we emphasize the importance of the professional preparation of the teacher student and the role of technological methods and means of communication in this preparation, we can not forget that the concern in general and the concern of teaching in particular may be one of the variables that affect the teacher student in the period of professional preparation as the teaching process represents a new position to him.

Williams Williams (1991) and Ghazi Ben Salah (2010) point out that teaching anxiety is a phenomenon experienced by many teachers in general and increased by teacher student s especially if the student realizes that there is someone who will evaluate the quality of his teaching. (34:57) (13:67) 
In spite of the fact that many scientific studies and conferences recommended focusing on the teacher preparation programs and the use of educational technology in the preparation programs such as the scientific conference for teacher formation (2004), the international conference towards better preparation for the teacher of the future (2004) And the Scientific Conference of the Arab Society for Educational Technology (2009). Despite the recent modern trends that call for the use of technological innovations, the teacher preparation programs are still facing problems and there is no interest in introducing technological innovations within these programs. These programs are still based on traditional methods, methods and methods. The teacher of the future is not good at dealing with modern technology in teaching and the researcher believes that it is necessary before we ask the teacher to teach using technology must learn to use himself during the period of preparation academically and professionally.

This was agreed upon by Walid Al-Halafawi (2011), Sulaiman Bin Saif AlGhunaimi (2007), Richard Bailey (2003), noting that the use of technological innovations in support of the teaching process and help the student to master the skills of teaching. (31: 128) (30:37) (27: 12)

As for the importance and necessity of technological innovations in the preparation of the teacher student, the researcher saw that the study uses one of the technological innovations (Tele Guide) to provide the teacher student feedback information immediately back to its performance during the implementation of the main part of the lesson as one of the non-traditional entries Taking into consideration, the psychological side of the teacher student of anxiety and tension during the process of teaching in order to develop teaching competencies and support to the teacher student during teaching.

\section{Research problem}


The problem of research is determined by monitoring the researcher for the way in which the teacher student is directed and to provide feedback while receiving field training in the different schools of education. It has been shown that the guidance is done in two ways. The first ,supervisor is to guide the student and evaluate his observations while the teacher is teaching, afterthat he is given feedback orally and he may not remember a lot of teaching positions that made a mistake, since these instructions are completed after the completion of this teaching that the information received as a feed is deferred to be unable to rectify the situation by the fact that the teaching has already ended up with him, which is difficult to behavior modification of teaching,

the second way is that the supervisor to call the student during the teaching and give him feedback to correct the error while in the position of teaching among students and this causes him in embarrassment and confusion, which results in anxiety and tension during the teaching. So the researcher that if the feedback is synchronized with Performance The student can receive the teacher alone without causing it to embarrass him in front of his students may have a positive impact in the modification of his behavior immediately and then lead to the correct teaching position and acquire the required teaching competencies.

Therefore, the researcher attempted to study using the electronic guidance device as one of the technological innovations through which the supervisor can provide the teacher with feedback information in parallel with the teaching of the main part of the lesson of sports education in order to learn about the effect of the use of electronic guidance on synchronized teaching competencies For the student the teacher and the extent of reduction of the anxiety of the student because of the device used.

\section{Research importance}

research importance is explained in the following: 
1. Using a device to guide the student electronically during the implementation of the main part of the lesson of physical education to provide him with immediate information and feedback during the repetition of teaching, which helps to modify the performance of the teaching during the same situation without causing confusion or embarrassment student.

2. To detect the impact of the use of synchronous Tele Guide to develop the teaching competencies of the teacher student and reduce the concern of teaching anxiety.

3. The current research is an attempt to follow the recent trends and its response to the recommendations of conferences and research, which indicated the need to employ technology in the preparation of the teacher.

\section{Research objectives:}

The aim of the research is to determine the effect of feedback using the synchronous Tele Guide during the implementation of the main part of the sport education lesson and achieve the goal through the following purposes

1.To identify the impact of the use of Tele Guide in the development of teaching competencies of the teacher student .

2. Identify the effect of using the electronic guidance device in reducing the student's anxiety about the teacher.

\section{Research hypotheses:}

- There are statistically significant differences between the pre - and post - test of the experimental (Test)group in the teaching competencies of the teacher students in the Faculty of Sports Education.

- There are statistically significant differences between the pre- and postmeasurements of the control group in the teaching competencies of the teacher students in the Faculty of Sports Education. 
There are statistically significant differences between the experimental group and the control group in the dimensional measurements in the teaching competencies of the teacher students in the college of sport education for the experimental group.

- There are statistical differences between the two dimensions of the experimental groups and the adjustment in the measure of anxiety

\section{Research terms and definitions:}

1. Synchronous electronic guidance:

The researcher defines the procedure as "an interactive process between the supervisor (the sender) and the teacher student (the reciever) is done when the supervisor to provide the teacher student with corrective feedback nutrition in parallel with the performance of teaching through the electronic guidance device in order to support and develop teaching competencies"

2 Teaching competencies: Kamal al-Din Hashim (2004) defines it as the ability of the teacher to employ a complex set of knowledge, behavior patterns and skills while performing his or her educational roles at a level no less than the level of proficiency that has been determined. (20:17)

3. Teaching anxiety:

The researcher knows that "it is a sense that the student has a teacher in the position of teaching makes him feel upset and tension and a sense of fear of failure in the exercise of teaching tasks and thus try to avoid the situation and escape from it"

4. Teacher student:

The researcher defines him as a student who conducts training in teaching and practices educational tasks within the field training course for the students of the college of sports education in order to improve his teaching competencies

\section{Literature review:}

1 - Hazem Ahmed Matroud, entzar Farouk Elias (2010) (14): The study aimed to identify the effect of the use of cooperative learning in reducing the level of anxiety and teaching the skill of transmission in the students of the preparatory stage 
volleyball where the study was based on experimental method using two groups (test group: 16 Student \& control group: 16student ) The most important results that the method of collaborative learning is an effective way to reduce the level of anxiety to teach students the technical performance of the skill of transmission. In addition to the superiority of the method of collaborative learning on the (traditional) method of learning the skill of transmission.

2 - Dina Metwally Ahmed Metwally (2008) (9): - The aim of the study was to identify the effect of a proposed program using the super-overlapping media on both the level of performance and anxiety in junior children in dolphin swimming. A sample of 16 students was selected (test group: 8):control proup (8) Beginners (9-10 years). The most important results were the higher mean scores of anxiety in the pre experimental measurments than the post measurment of the test group, in addition to the improvement in the level of technical performance and the digital level of (dolphin swimming )test and control groups for the test group

3 - Heba Said Abdel Moneim (2009) (16): - The aim of the study was to build an educational web site and to know its effect on the acquisition of some teaching skills among students of practical education in the teaching department in the Faculty of Physical Education in Tanta using the experimental method. ), Where the study reached several results, the most important of which is that the educational site contributed positively to improve the performance of teaching skills as well as the level of cognitive achievement of the control group members in addition to the educational site has a better effect than the method of indoctrination ,explanation and performance model in improving the performance of the teaching skills and improving the level of cognitive achievement

4 - Essam El Din Mohamed Azmi, Haitham Abdel Magid Mohamed (2006) (11): - The study aimed to detect the effect of an educational program using virtual reality technology on some of the teaching skills of the teacher student at Teaching 
speciality Faculty of Physical Education Minia University, where the study used the experimental method, The sample was chosen by the vertical method of (20) students of the fourth year of the teaching department, the study reached several results, the most important of which is that the educational program using virtual reality technology has a positive effect on the development of teaching skills of the student in question compared to the method based on The performance of a model within the lesson, in addition to the virtual learning environment, creates an interactive learning environment that attracts the attention of learners based on the principle of enjoyment and observation before practice.

5 - Amr Abdellah Abdel Kader (2014) (33): - The aim of the study was to design a program using the mobile phone as an external review and to identify its impact on both the level of cognitive achievement and the skillful performance of the hate of the pill designed by the second group to request the Faculty of Education (test group: 17) (control group: 13) of the students of the second year in the faculty of physical Education, Damietta University, where the results confirmed the impact of the program. Using mobile phone has a positive impact on cognitive achievement and learning skills for attacking skills in basketball which already in the curriculum for the second year students.

\section{Research procedures:}

1. Research methodology: The researcher used the experimental method because of its relevance to the nature of the research using the experimental design of two groups, one test and the other control by the pre\&post measurement method for each.

\section{Research domains:}

- Human domain: Teacher students at the Faculty of Physical Education for Boys Alexandria University

- Temporal domain: First semester of the academic year 2015/2016

\section{Research community and sample:}


I) Research community: The research society was selected by the students of the third academic year because it conducts the field training in the primary education schools, and the students did not previously perform the external field training and therefore did not experience the actual teaching positions.

II) Research main sample: The sample of the research was selected by random way among the students who perform field training in four schools in the eastern part of Alexandria in the Alexandria governorate. The sample size was twenty students divided into two equal groups, test group which was used experiment variable with The teaching (Tele Guide) and the number of ten teacher students while I use with the control group traditional methods to guide students during teaching has been the number of ten students.

III) Sample survey study: It consisted of ten students from the same research community, but outside the main sample of the research and to conduct surveys on that sample, bringing the total sample size 30 students and $10 \%$ of the total population of the research.

\section{Homogeneity of the sample: -}

The homogeneity of the sample was calculated as shown in Table (1)

Table (1) Statistical description of the data of the research main sample in teaching competencies before the experiment $n=10$

\begin{tabular}{l||l||l||l||l||l||l|l}
\hline \hline Variables & $\begin{array}{l}\text { Unit of } \\
\text { measurment }\end{array}$ & minimum & maximum & Mean & $\begin{array}{l}\text { Standard } \\
\text { deviation }\end{array}$ & $\begin{array}{l}\text {. Skewness } \\
\text { coefficient }\end{array}$ & $\begin{array}{l}\text { Kurtosis } \\
\text { coefficients }\end{array}$ \\
\hline \hline $\begin{array}{l}\text { The total } \\
\text { score of } \\
\text { teaching skills } \\
\text { note card }\end{array}$ & $\begin{array}{l}\text { Degree(mar } \\
\text { k) }\end{array}$ & 30.00 & 44.00 & 38.75 & 3.40 & $-0 . .83$ & 1.31 \\
\hline \hline
\end{tabular}

It is clear from Table (1) the homogeneity of the main research data prior to the experiment that the.Skewness was (0.83). This indicates that the measurements 
obtained are close to the mean. The values of the skewness are very close to zero.also, Kurtosis was (1.31)This means that the oscillation of the average curve is acceptable, on average, and not oscillating up or down. This confirms the homogeneity of the members of the main research group (test and control) in the teaching skills note before the experiment and that each group harmonizes the data of its members.

Sample Parity: To ensure the equivalence of the study groups before the application of the main experiment, the note card of teaching competencies was applied to the sample students. The mean difference of the pre measurements of the test and control groups was calculated as shown in Table (2)

Table (2) Significance of differences between the test and the control group in the note card of teaching competencies prior to the experiment (equivalence)

\begin{tabular}{|c|c|c|c|c|c|c|}
\hline Statistical significance & \multicolumn{2}{|c|}{$\begin{array}{c}\text { Test group } \\
\mathrm{N}=10\end{array}$} & \multicolumn{2}{|c|}{$\begin{array}{c}\text { Control group } \\
\qquad \begin{array}{l}\mathrm{N}=10\end{array}\end{array}$} & $\begin{array}{l}\text { The difference } \\
\text { between the two } \\
\text { means }\end{array}$ & T value \\
\hline $\begin{array}{l}\text { The total score of teaching skills } \\
\text { note card }\end{array}$ & 39.90 & 2.33 & 37.60 & 4.01 & 2.30 & 1.57 \\
\hline
\end{tabular}

Table (2) shows the difference between the test and the control group in the main primary measurements. The calculated value of $(\mathrm{T})$ is 1.57 and the value is insignificant and less than the tabulated value of 0.05 , indicating no differences between the two groups and that there is a parity between the Test and control groups in the note card teaching competencies before the experiment.

\section{Data collection tools:}

The researcher used some devices to conduct and apply the research and some tools to collect the data as follows: 
I) the electronic guidance device is a mean of communication that allows the supervisor to direct the teacher student simultaneously while teaching and through it can be provided with immediate feedback and information on the performance of the teaching to correct the errors that occur in it and then be able to modify the behavior of teaching immediately in the same teaching position, And the use of the electronic guidance device limits the intervention of the supervisor to guide the teacher student, which causes him to be in confusion, embarrassment and tension and in front of students and lose the desire to continue teaching. appendix (1)

II) video camera: used to take photos to the lessons carried out by the teacher students either in the test group or the control group at the beginning and end of the period of experimental application to assess the teaching competencies of the teacher student .

\section{III) Note Card of the teaching competencies:}

The researcher prepared a list of instructional competencies as indicated by several studies, including Fathi Youssef Rasheed (2002), 22 Ali Muhammad Saleh (2002), 20 The card has been included in its initial form on the number of 32 teaching facilities, Appendix(2) represented in the competencies of the implementation of the main part of the lesson of sports education and to prepare the note card of the teaching competencies these were followed:

A - Identify the purpose of the note card of the teaching competencies.

B - Defining the phrases that represent the competencies necessary for the implementation of the main part of the lesson of sports education.

C-Presentation of the card to experts in the curricula and methods of teaching to determine their validity and linguistic integrity.

D-As indicated by the experts, some phrases have been modified so that the card in its final form is composed of (22) teaching competencies and became valid for use as a measure. Appendix(3) 
Scientific treatments of the note card of teaching competencies:

\section{Validity of the note card}

A-validity of judges: it was found when the card (appendix3) was presented to a group of specialists in the curriculum and methods of teaching (appendix5) to express opinion on them, and from the judges' remarks, some of the statements were modified by rewording the linguistic and scientific language and deleting some of the phrases and the card In its final form,appendix $(3)$ is composed of (22) teaching competencies. The researcher has accepted the acceptance of the opinions which exceeded $75 \%$, and this is evidence of its validity and validity to measure teaching competencies.

B - The validity of the peripheral comparison: The researcher used the validity of the peripheral comparison (the lower quartile and upper quartile) in the note of teaching competencies on a random sample and outside the main sample of the research,

Table 3: Comparative comparison between the highest quartile and the lowest quartile in the teaching skills note card

\begin{tabular}{|c|c|c|c|c|c|c|c|c|}
\hline \multirow[t]{2}{*}{$\begin{array}{l}\text { Statistical } \\
\text { significance }\end{array}$} & \multirow[t]{2}{*}{$\begin{array}{l}\text { Unit of } \\
\text { measurment }\end{array}$} & \multicolumn{2}{|c|}{$\begin{array}{l}\text { Highest quartile } \\
\mathrm{N}=3\end{array}$} & \multicolumn{2}{|c|}{$\begin{array}{l}\text { lowest quartile } \\
\mathrm{N}=3\end{array}$} & \multirow[t]{2}{*}{$\begin{array}{l}\text { Mean } \\
\text { difference }\end{array}$} & \multirow[t]{2}{*}{$\begin{array}{l}\mathrm{T} \\
\text { value }\end{array}$} & \multirow[t]{2}{*}{ Validity } \\
\hline & & Mean & $\begin{array}{l}\text { Standard } \\
\text { deviation }\end{array}$ & Mean & $\begin{array}{l}\text { Standard } \\
\text { deviation }\end{array}$ & & & \\
\hline $\begin{array}{l}\text { Note card of } \\
\text { teaching } \\
\text { competencies" } \\
\text { skills" }\end{array}$ & value & 39.00 & 20.00 & 33.33 & 0.58 & 5.67 & *4.71 & 0.16 \\
\hline
\end{tabular}

* Significant at the level of 0.05 where the tabulated(T)value at the level of $0.05=$ 2.26

Table (3) shows the validity of the comparative comparison between the lowest quartiles and the upper quartiles. The calculated value of the computed values was 4.71, which is greater than the tabulated value at the level of 0.05 .

- Reliability of note card of teaching competencies: 
The note card was applied to a sample of (10) students from the research community and from outside the main sample. The application was re-applied after (10) and table (4) descibe this.

Table (4) The significance of the differences between the first and second application in the note card teaching competencies $\mathrm{N}=10$

\begin{tabular}{l||l|l||l|l||l||l||l||l|}
\hline \hline Variables & \multicolumn{2}{|l|}{ First application } & \multicolumn{2}{|l||}{$\begin{array}{l}\text { Second } \\
\text { application }\end{array}$} & Mean difference & T value & $\begin{array}{l}\text { (R) } \\
\text { Value } \\
\text { (reliability }\end{array}$ \\
\cline { 2 - 7 } & mean & $\begin{array}{l}\text { Standard } \\
\text { deviation }\end{array}$ & Mean & $\begin{array}{l}\text { Standard } \\
\text { deviation }\end{array}$ & mean & $\begin{array}{l}\text { Standard } \\
\text { deviation }\end{array}$ & & \\
\hline \hline $\begin{array}{l}\text { Note card of } \\
\text { teaching } \\
\text { competencies } \\
\text { "skills" }\end{array}$ & 35.80 & 2.66 & 35.90 & 1.37 & -0.10 & 1.91 & -0.17 & .726 \\
\hline \hline
\end{tabular}

Was significant at 0.05 , where the tabulated $(\mathrm{T})$ value at $0.05=2.26$

Tabulated $(\mathrm{R})$ value at $0.05=0.602$

Table (4) shows the differences between the first application and the second application in the note of teaching competencies to find the reliability coefficient. The calculated $(\mathrm{T})$ value was 0.17 and this value is less than the tabulated value at 0.05 level,also, calculated $(\mathrm{R})$ value $=(0.726)$. This value is greater than the tabulated $(\mathrm{R})$ value at 0.05 level, which confirms that the note card for the teaching competencies of the teacher student $\mathrm{s}$ is Reliable and thus has become honest, stable and applicable.

\section{IV) the measure of teaching anxiety:}

The researcher designed the anxiety scale after reviewing several scientific references and reference studies on the subject of teaching anxiety, including Ahmed Fawzi (2006) (4), Muhammad Alawi (2007) (23), Dina Metwally (2008) (9), Ahmad Gomaa (2012) (5). The objective of the standard is to identify the level of teaching anxiety of the teacher students as well as to determine the main dimensions of the scale. These dimensions were represented in the following: 
The first dimension: cognitive levels

Second dimension: confidence in self

Third Dimension: Physical Symptoms The terms of the scale were made up of 22 terms ,so that

1 - not to start the phrase by the word no but with a behavior.

2 - the phrase not to include more than one thought.

3 - use variety of phrases so that some positive and some negative.

4- The phrase should be independent so that the answer to the individual one does not suggested to be answer for another one.

To express opinion on the scale and based on the opinions of the experts. The researcher was satisfied with (85\%) according to the experts' responses on the scale. The results of the expert survey were to determine Three dimensions of the scale are: (cognitive levels - self confidence - physical symptoms) contains (22) single phrase . appendix 4

The Likert scale was used to compute the degree of response to the interviewees (always - sometimes - never). This is expressed in the scores $(3,2,1)$ of the positive phrases, $(1,2,3)$ of the negative phrases

\section{Scientific coefficients of the measure of teaching anxiety}

The validity of the measurements: was calculated by finding the coefficient of internal consistency between the unit with its dimension and between the unit and the total grade of the scale. Table (5) shows the validity of the scale

Table (5) The coefficient of internal consistency between dimensions, phrases, and the total score of the measure of academic concern (validity of measurment)

\begin{tabular}{l||l||l|l}
\hline \hline Dimension & phrase & $\begin{array}{l}\text { Correlation coefficient } \\
\text { with dimension }\end{array}$ & $\begin{array}{l}\text { correlation Coefficient with the } \\
\text { total grade of the scale }\end{array}$ \\
\hline \hline \multirow{2}{*}{$\begin{array}{l}\text { The first dimension } \\
\text { Cognitive levels }\end{array}$} & 1 & .783 & .716 \\
\cline { 2 - 4 } & 2 & .662 & .660 \\
\cline { 2 - 4 } & 3 & .644 & .617 \\
\cline { 2 - 4 } & 4 & .742 & .850 \\
\hline
\end{tabular}




\begin{tabular}{|c|c|c|c|}
\hline & 5 & .803 & .714 \\
\hline & 6 & .684 & .832 \\
\hline & 7 & .680 & .726 \\
\hline & 8 & .651 & .638 \\
\hline \multirow{8}{*}{$\begin{array}{l}\text { Second dimension } \\
\text { Self confidence }\end{array}$} & $\overline{11}$ & 7.701 & .619 \\
\hline & 2 & .820 & .643 \\
\hline & 3 & .693 & .619 \\
\hline & 4 & .801 & .794 \\
\hline & 5 & .880 & .806 \\
\hline & 6 & .702 & .629 \\
\hline & 7 & .654 & .748 \\
\hline & 8 & .723 & .887 \\
\hline \multirow[t]{2}{*}{ third dimension } & 1 & .692 & .784 \\
\hline & 2 & .681 & .785 \\
\hline \multirow[t]{4}{*}{ Physical symptoms } & 3 & .830 & .656 \\
\hline & 4 & .782 & .870 \\
\hline & 5 & .834 & .729 \\
\hline & 6 & .646 & .635 \\
\hline
\end{tabular}

It is clear from Table (5) that there is a statistical relationship at the level of 0.05 between the scores of each phrase and the dimension as well as the total grade of the scale. This supports the internal consistency as an indicator of the validity of the anxiety scale.

Reliability of the measure of teaching anxiety: - The coefficient of reliability of the scale was calculated in terms of half-sum and Fahrkonbach coefficient to estimate the coefficient of total reliability of the scale. The scale was applied to the sample of the survey study and the number of (10) teacher students from the eastern region of Alexandria educational in the province of Alexandria to calculate the coefficient of reliability of the measure of learning anxiety and table (6) refers to the coefficient of constancy.

Table (6) The reliability of the anxiety scale by the half-sum and the alphacronbach coefficient $\mathbf{n}=\mathbf{1 0}$

\begin{tabular}{l|l||l||l}
\hline \hline & Dimension & half-sum & Cronbach alpha \\
\hline \hline
\end{tabular}




\begin{tabular}{l||l||l|l||l}
\hline \hline \multicolumn{1}{l||}{} & \multicolumn{2}{|l|}{ coefficient } \\
\hline \hline 1 & The first dimension is cognitive levels &, 932 &, 941 &, 841 \\
\hline \hline 2 & The second dimension is self-confidence & 854, & 872, &, 756 \\
& & & & \\
\hline \hline 3 & The third dimension is physical symptoms &, 791 & 873, &, 745 \\
\hline \hline 4 & Teaching anxiety scale &, 844 & 905, &, 832 \\
\hline \hline
\end{tabular}

It is clear from Table (6) that the values of correlation coefficients in the half sum of the dimensions of the anxiety scale were ranged between (873 and 941) and that the Cronbach's Alpha coefficient reliability was between (754 and 840) The study has high reliability.

Determine the appropriate time for the scale:

The time of the scale was calculated by applying it to 10 of the teacher students who represent the sample, where the response time was calculated divided by the number of them. The result was 15 minutes. Accordingly, the time was applied when applying the standard to the main sample in the pre- and postmeasurements.

The following is a table (7) showing the final image of the number of standard items in each dimension of the scale and the number of positive and negative items Each with a measure of teaching anxiety.

\section{Table (7)}

The final image of the measure of academic concern and the number ofphrases of each dimension and its negative and positive phrase

\begin{tabular}{|c|c|c|c|c|c|c|}
\hline \multirow[t]{2}{*}{ dimensions } & $\begin{array}{l}\text { No. of } \\
\text { phrases of }\end{array}$ & \multirow[t]{2}{*}{ Type } & \multirow{2}{*}{\begin{tabular}{|l|} 
Total \\
of \\
phrases
\end{tabular}} & \multirow[t]{2}{*}{$\begin{array}{l}\text { No of each } \\
\text { phrase }\end{array}$} & \multicolumn{2}{|c|}{$\begin{array}{l}\text { Score for each } \\
\text { dimension }\end{array}$} \\
\hline & $\begin{array}{l}\text { each } \\
\text { dimension }\end{array}$ & & & & minimum & maximum \\
\hline
\end{tabular}




\begin{tabular}{|c|c|c|c|c|c|c|}
\hline $\begin{array}{l}\text { The first } \\
\text { dimension }\end{array}$ & & Positive & 2 & $16 \cdot 20$ & & \\
\hline $\begin{array}{l}\text { Cognitive } \\
\text { levels }\end{array}$ & 8 & negative & 6 & $1 \cdot 2 \cdot 8 \cdot 9 \cdot 14 \cdot 22$ & 8 & 24 \\
\hline$\overline{\text { Second }}$ & & Positive & 4 & $3 \cdot 6 \cdot 11 \cdot 13$ & & \\
\hline $\begin{array}{l}\text { dimension } \\
\text { Self } \\
\text { confidence }\end{array}$ & 8 & negative & 4 & $7 \cdot 10 \cdot 12 \cdot 21$ & 8 & 24 \\
\hline The third & & Positive & 4 & 18 & & \\
\hline $\begin{array}{l}\text { dimension } \\
\text { is physical } \\
\text { symptoms }\end{array}$ & 6 & negative & 5 & 4 4،5،15،17،19 & 6 & 18 \\
\hline total & 22 & & 22 & & 22 & 66 \\
\hline
\end{tabular}

It is clear from Table (7) that the number of the final vocabulary of the measure of anxiety of teaching (22) is single and the total grade of the scale ranges from 22 degrees to a maximum of 66 degrees.

Pre experiment measurements:

After the completion of the preparation of the research tools, pre experiment measurements were applied in the period (from Wednesday, 7/10/2015 to Wednesday, 14/10/2015) to the test and control groups in the variables under consideration, where each teacher student of the sample members teach the main part of the lesson These lessons were photographed and evaluated using the note of teaching competencies .appendix(3)

\section{Survey Study}

The researcher conducted a targeted survey 
1. Ensure that the electronic guidance device is suitable for the place of instruction.

2. Review of electrical connections.

3 . The student enables the teacher to use the electronic guidance device correctly and enable it to be installed so as not to be a hindrance in his movement.

4. Ensure the area that can be covered by the use of the device during the movement of the teacher student.

\section{Main research procedures}

The electronic guidance device was used with the test group, which allows direct communication between the supervisor and the student during the student's teaching process within the sports education quota. The use of the electronic guidance device was limited to the main part of the lesson and its duration (20 minutes), since the student must achieve through the goal of the main lesson which is to teach and install skills and therefore the supervisor during the teaching of the teacher student to provide immediate feedback on the performance of teaching ,Thus, the student can correct and rectify the error immediately after hearing the guidance of the supervisor through the electronic guidance device and thus correct the teaching position and acquire sufficient teaching in practice and in a confidential manner without causing tension or concern for the teacher student, but the control group has had all the conditions that were available to the experimental(test) group Both in terms of the number of lessons where the teacher student taught (12) lesson and all the possibilities and tools and area of the course that was available to the students of the test group except that the provision of the teacher student feedback information was done after the completion of the teaching, which does not allow The student to have the opportunity to adjust his / her teaching performance in the same academic position in which he has made a mistake.

\section{Post experimental measurements}


After the completion of the research, the measurements were carried out on both the students of the test and the control group where the card was applied to the teaching competencies as well as the educational anxiety scale in the period from $21 / 12 / 2015$ to $28 / 12 / 2015$. The data were collected and analyzed and then view and to discuss the results.

- Statistical treatments: Statistical treatments were found using SPSS version 2020 as follows:

(Mean-Standard deviation -median- Kurtosis- skewness- validity -reliabilityDifficulty Ease Test - $(\mathrm{t})$ test -mean difference-percentage\%- Percentag of Improvement \%)

\section{Results and discussion}

- First: Presentation and discussion of the results of the pre and post measurement of the test group card note of teaching competencies

Table (8)

Special statistical indications of the Note card of the teaching competencies and the percentage of improvement of the test group before and after the experiment

$$
\mathbf{N}=\mathbf{1 0}
$$

\begin{tabular}{|c|c|c|c|c|c|c|c|c|}
\hline $\begin{array}{l}\text { statistical } \\
\text { significance }\end{array}$ & $\begin{array}{l}\text { Pre ex } \\
\text { meast }\end{array}$ & $\begin{array}{l}\text { periment } \\
\text { rement }\end{array}$ & $\begin{array}{l}\text { Post e } \\
\text { measu }\end{array}$ & $\begin{array}{l}\text { periment } \\
\text { rement }\end{array}$ & $\overline{~ M e a n ~}$ & difference & $\begin{array}{l}\text { T } \\
\text { value }\end{array}$ & $\begin{array}{l}\text { Thepercentag } \\
\text { e of }\end{array}$ \\
\hline variable & $\begin{array}{l}\text { Mea } \\
\text { n }\end{array}$ & \begin{tabular}{|l} 
Standar \\
d \\
deviatio \\
n
\end{tabular} & $\begin{array}{l}\text { Mea } \\
\text { n }\end{array}$ & $\begin{array}{l}\text { Standar } \\
\text { d } \\
\text { deviatio } \\
\text { n }\end{array}$ & $\begin{array}{l}\text { Mea } \\
\text { n }\end{array}$ & $\begin{array}{l}\text { Standar } \\
\text { d } \\
\text { deviatio } \\
\text { n }\end{array}$ & & $\begin{array}{l}\text { improvement } \\
\%\end{array}$ \\
\hline Note card & 39.90 & 2.33 & 74.30 & 5.54 & 34.40 & 5.46 & $9.92 *$ & 86.22 \\
\hline
\end{tabular}




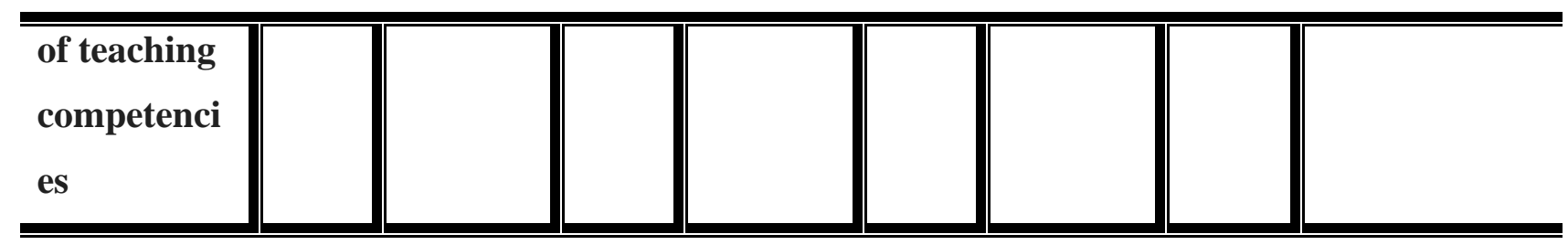

Significant at the level $0.05=2.31$

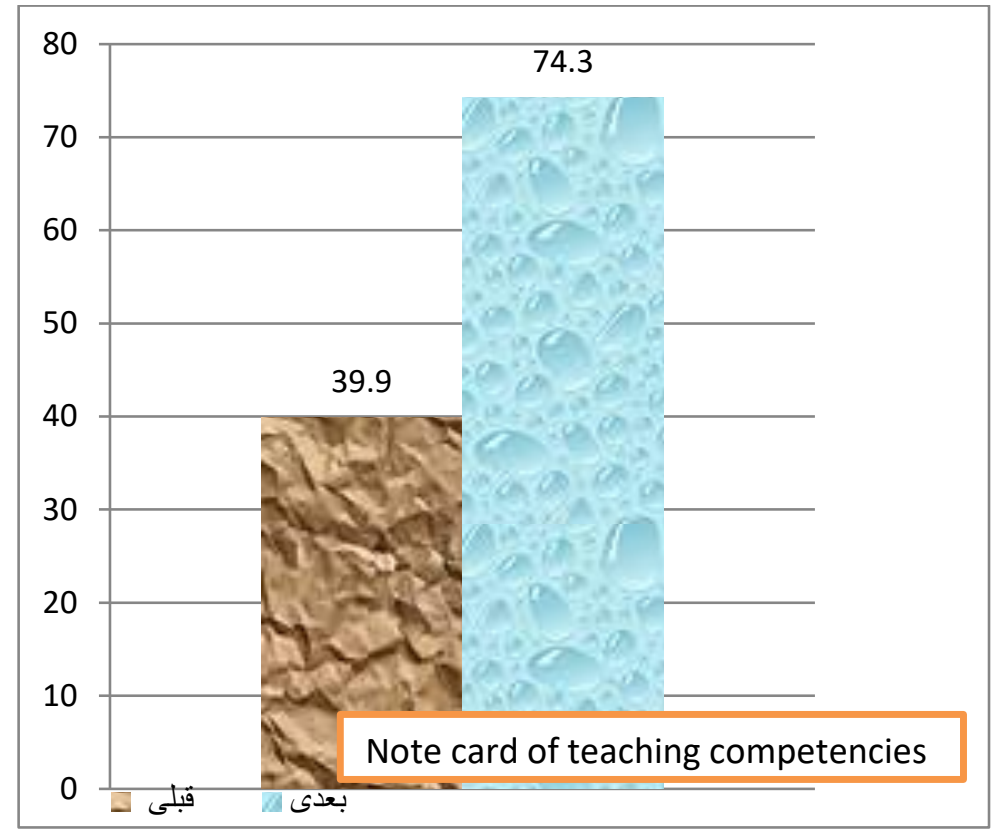

Figure (1) shows the averages in the pre- \& post- measurements of the test group in the total of the words of the note card of teaching competencies

Table (8) and Figure (1) for the statistical significance of the total of the expressions of the teaching skill note card and the percentage of improvement for the test group before and after the experiment are shown: There are statistically significant differences at (0.05) 9.92), which is greater than the value of (T) in the table at $(0.05)=(2.31)$, and the percentage of improvement in the total of the words of the teaching skill note card $(86.22 \%)$ for the benefit of post measurement of the test group. This is due to the use of the electronic guidance device and providing immediate feedback to the teacher student, which led to the development of teaching competencies significantly

This is in line with Ibrahim Al-Wakil's view (2002) that it requires that the programs and methods of teacher training be subject to continuous development to increase 
efficiency and increase their effectiveness in accordance with the changes and developments occurring in the societies and the new variables that they must take into consideration when preparing the teacher. Experimental is one of the modern devices which are based on electronic communication. (18: 207)

These findings are also consistent with the view of Walid Al-Halafawi (2011), Sulaiman Bin Saif Al-Ghunaimi (2007) and Richard Bailey (2003) that the use of technological innovations is in support of the teaching process and helps the student master his teaching performance. (31: 128) (30:37) (27:12)

Since the electronic guidance used with the test group is based on the theory of rapid communication between supervisor and teacher student, the results of this group are consistent with the view of Youssef Diab Awad, Magdy Ali Zamil (2010) that communication is necessary in the teaching and learning, and the task of workers in the field of education in general, And the teacher and students in particular, where he communicates on the transfer of ideas, information, trends and sensitivities from individual (sender) to another (reciever), or to a group of individuals. In order for the communication to be effective and active, the environment, channel and tools must be created for this purpose, in addition to the presence of the powerful, effective sender in the students (receptors) of the message. (32: 52)

These findings are consistent with the findings of Reem Nashad (2005(26), (Nahed Abdel Rady, 2009)(25) The use of communication technology leads to rapid and noticeable progress in teacher preparation, as it avoids traditional methods that relay on The studies confirmed that continuous communication between the student and the teacher contributes to overcoming the difficulties encountered in the process of teaching and thus become more able to experience, knowledge and teaching competencies necessary to teach For physical activity in the Physical Education lessons.

This progress has been achieved by the validity of the first hypothesis and the existence of differences of statistical significance between the pre and post 
measurement of the test group in the teaching competencies of the teacher students in the faculty of Sports Education.

II) Presentation and discussion of the results of the pre and post measurement of the control group of the note cardof teaching competencies

Table (9)

Special statistical significance, Note card of the teaching competencies and the percentage of improvement of the control group before and after the experiment

$$
\mathbf{n}=\mathbf{1 0}
$$

\begin{tabular}{|c|c|c|c|c|c|c|c|c|}
\hline \multirow{2}{*}{$\begin{array}{l}\text { Statistical } \\
\text { significance } \\
\text { variable }\end{array}$} & \multicolumn{2}{|c|}{ Pre measurment } & \multicolumn{2}{|c|}{$\begin{array}{l}\text { Post } \\
\text { measurment }\end{array}$} & \multicolumn{2}{|c|}{ Mean difference } & \multirow{2}{*}{$\begin{array}{l}\mathrm{T} \\
\text { value }\end{array}$} & \multirow{2}{*}{$\begin{array}{l}\text { Percentage } \\
\text { of } \\
\text { improvement } \\
\%\end{array}$} \\
\hline & mean & $\begin{array}{l}\text { Standard } \\
\text { deviation }\end{array}$ & mean & $\begin{array}{l}\text { Standard } \\
\text { deviation }\end{array}$ & mean & $\begin{array}{l}\text { Standard } \\
\text { deviation }\end{array}$ & & \\
\hline $\begin{array}{l}\text { Note card of } \\
\text { teaching } \\
\text { competencies }\end{array}$ & 37.60 & 4.01 & 51.80 & 4.92 & 14.20 & 5.37 & $8.36^{*}$ & 37.77 \\
\hline
\end{tabular}

Significant when $0.05=2.31$

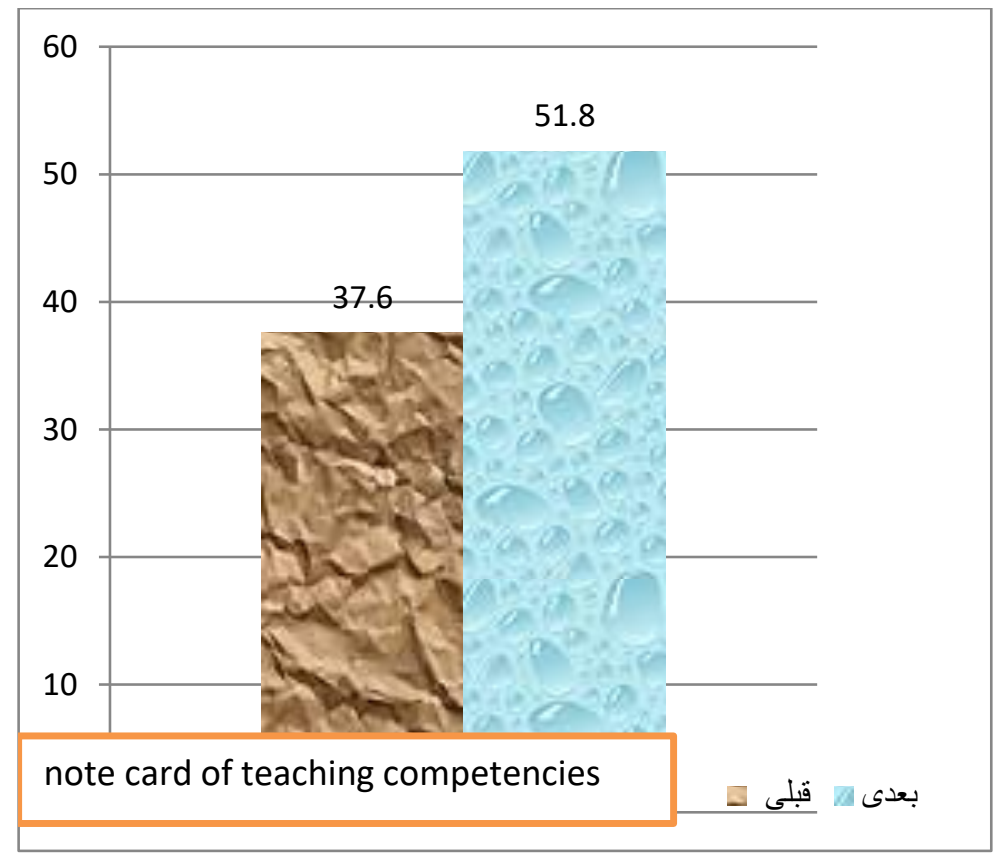


Figure(2) shows The mean in the pre\&post measurements of the control group are shown in the total of the phrases of the teaching skill note card

Table (9) and Figure (2) for the statistical significance of the total of the expressions of the teaching skill note and the percentage of improvement $\%$ of the control group before and after the experiment are shown: There are statistically significant differences at (0.05) 8.36), which is greater than the value of (T) table at $(0.05)=(2.31)$, and the percentage of improvement in the total of the words of the teaching skills note card (37.77\%) for the benefit of the post measurement of the control group.

The researcher attributed this improvement to the nature of the way between the supervisor and the teacher student through the follow-up performance of the teaching during the process of teaching and then correct the mistakes after the completion of teaching, which leads to improvement through the repetition of the work during the period of research as well as the status of control group students in Teaching positions and teaching process and direct interaction during the implementation phase of physical education lesson, and the commitment and continuity throughout the research period and the responsibility of the process of teaching made them always strive to try to succeed. All this has helped to improve the teaching competencies of the students in the control group.

These results are consistent with the results of the Heba Said study (2009) (16)The teaching of the control group in the manner of indoctrination has improved the performance of teacher students and has given students practical experience that has raised their level. Collective learning has stimulated students' motivation to compete Among them to highlight the superiority of each other.

Adnan Darwish Jaloun (1998), Samia Farghali, Nadia Abdelkader (2002) and Ashraf Al-Shahat (2008) emphasize field training as a field in which different 
professional attitudes are formed and reflect different concepts about learning content, learner nature, characteristics, and interaction. The need to help teacher students master the teaching skills (planning - implementation - assessment).

\section{$(3: 124)(28: 283)(7: 11)$}

This progress has been achieved in the validity of the second hypothesis and the existence of differences of statistical significance between the pre and post measurement of the control group in the teaching competencies of the teacher students in the faculty of Sports Education.

Third: Presentation and discussion of the results of the statistical significance of the totalphrases of the note card of teaching competencies of the test and control groups after the experiment

Table (10)

Statistical Significance Note card OF the teaching competencies of the test and control groups after the experiment

$$
\mathbf{N}=\mathbf{2 0}
$$

\begin{tabular}{|c|c|c|c|c|c|c|c|}
\hline $\begin{array}{l}\text { Statistical } \\
\text { significance }\end{array}$ & $\begin{array}{l}\text { Test g } \\
\mathrm{N}=10\end{array}$ & oup & $\begin{array}{l}\text { Contr } \\
\mathrm{N}=10\end{array}$ & group & $\begin{array}{l}\text { Mean } \\
\text { difference }\end{array}$ & $\begin{array}{l}\mathrm{T} \\
\text { value }\end{array}$ & $\begin{array}{l}\text { Difference } \\
\text { percentage \% }\end{array}$ \\
\hline Variable & mean & \begin{tabular}{|l} 
Standard \\
deviation
\end{tabular} & mean & $\begin{array}{l}\text { Standard } \\
\text { deviation }\end{array}$ & & & \\
\hline $\begin{array}{l}\text { Note card of } \\
\text { teaching } \\
\text { competencies }\end{array}$ & 74.30 & 5.54 & 51.80 & 4.92 & 22.50 & $9.61 *$ & 43.44 \\
\hline
\end{tabular}

Significant when $0.05=2.10$ 


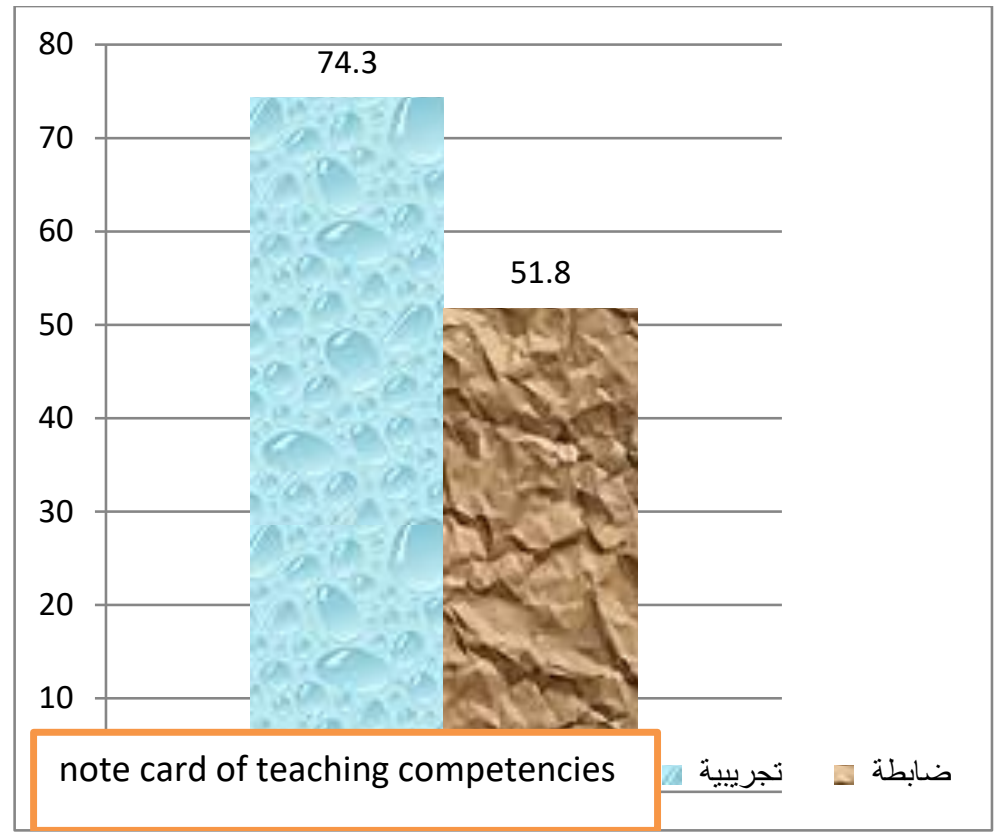

Figure (3) shows the averages in the post measurements of the test and control groups in the note card teaching competencies

Table (10) and Figure (3) for statistical significance of the total scores of the note of the teaching competencies of the test and control groups after the experiment were shown: There were statistically significant differences at (0.05) (9.61). This value is greater than the tabulated value at $(0.05)=(2.10)$ and the significance level is less than 0.05 .

The researcher attributed this progress to the nature of the electronic guidance device, which allows immediate communication and provide feedback on the teaching performance of the student in the process of teaching, as the use of communication technology leads to rapid and noticeable progress towards achieving the desired goals is the development of a competent teacher able to assume responsibility, Reduce the traditional programs of teacher preparation and take an important step towards the preparation based on borrowing from modern technology means that help to develop their teaching competencies, which is sought by the researcher through the use of electronic communication device and The dimension 
helps in the development of teaching competencies for the process of indoctrination and dumping.

These findings are consistent with the views of Yusuf Diab Awad and Majdi Ali Zamil (2010) that communication is a necessary process in the teaching and learning process, as it communicates on the transfer of ideas, information, attitudes and sensitivities from individual (sender) to other (reciever) Of individuals. In order for the communication to be effective and active, it is necessary to create the environment, the channel and the appropriate tools for this, in addition to the presence of the powerful, influential sender in the students (receptors or recievers) of the message. (32: 53)

The feedback is important and has an effective role in the educational situation as it works to promote and guide the communication process between individuals if it is understood and possible to comply with the conditions of submission, and thus more effective in the rationalization of education because it helps the learner to find out his mistakes, A feed that was reviewed immediately through the electronic guidance, which caused a significant difference in the results of the researcher for the benefit of the test group and agree with the view of both Islam Salem (2007) Mahmoud Abdel Halim Abdel-Karim (2006), Talib Al-Masoudi (2002), Marwan Abdel-Majid Ibrahim (2002) Hudi Abd Al-Samee (2000), that immediate feedback relates to and tracks behavior observed directly, and provides the learner with the necessary information and guidance To promote, develop or correct the behavior. Circumstances . (10:43) (21:7) (15:69) (22: 57) (17:18)

This achieved the validity of the third hypothesis and the existence of differences of statistical significance between the test and the control group in the post measurements in the teaching competencies of the teacher students in the Faculty of Sports Education for the benefit of the test group 


\section{Discussion of the results}

Second, to present and discuss the results of the educational anxiety scale

To verify the validity of the hypothesis, there were statistically significant differences between the post measurments of the test and control groups in the second anxiety scale. Manwetney test was used to determine the mean differences between the students of the test and control group in the level of anxiety. And Table (11) shows this

\section{Table (11)}

Significance of the mean differences between the grades of students of the test and control groups in the dimension measurement of the educational anxiety scale and the results of the effect size

\begin{tabular}{|c|c|c|c|c|c|c|c|}
\hline \multirow{2}{*}{$\begin{array}{l}\text { Measurement } \\
\text { dimensions }\end{array}$} & \multicolumn{2}{|c|}{$\begin{array}{l}\text { Test group } \\
\mathrm{N}=10\end{array}$} & \multicolumn{2}{|c|}{$\begin{array}{l}\text { Control group } \\
\mathrm{N}=10\end{array}$} & \multirow[t]{2}{*}{$\overline{\mathrm{U}}$} & \multirow[t]{2}{*}{$\overline{\mathbf{Z}}$} & \multirow{2}{*}{$\begin{array}{l}\text { Effect size } \\
\text { rpb }\end{array}$} \\
\hline & $\begin{array}{l}\text { Mean of } \\
\text { grades }\end{array}$ & \begin{tabular}{|l} 
Total of \\
grades
\end{tabular} & $\begin{array}{l}\text { Mean of } \\
\text { grades }\end{array}$ & $\begin{array}{l}\text { Total of } \\
\text { grades }\end{array}$ & & & \\
\hline $\begin{array}{l}\text { The first dimension } \\
\text { Cognitive levels }\end{array}$ & 13,25 & 132,500 & 4,500 & 45,00 & $\overline{1,00}$ & $3,40^{*}$ & 1,00 \\
\hline $\begin{array}{l}\text { Second dimension } \\
\text { Self confiedence }\end{array}$ & 13,90 & 139,00 & 4,81 & 48,10 & 2,50 & $3,13^{*}$ & 0,923 \\
\hline $\begin{array}{l}\text { Third dimension } \\
\text { Physical symptoms }\end{array}$ & 12,81 & 128,10 & 5,19 & 51,90 & 5,50 & $2,95^{*}$ & 0,828 \\
\hline
\end{tabular}


Table (11) shows that the mean differences between th grades $(Z)$ ranged between $(3,40,295)$ indicating that the statistical differences between the test group and the control group in the teaching anxiety and $\mathrm{Z}$ values calculated in all dimensions of the scale is greater than The scale of the effect of the use of the electronic guidance device ranged from 1.00 to 0.828 and this indicates that the magnitude of the effect is from strong to very strong.

The researcher attributed the results shown in the previous table to the fact that the use of the electronic guidance device in which the student received the guidance to correct the performance of the student has contributed to reducing the student's anxiety The student became more confident in himself during teaching, which confirms the effectiveness of the electronic guidance device,

The results are consistent with the findings of Hazem Rashed (2007)(15), Dina Metwally (2008)(9), Hazem Matroud and entzar Elias (2010) (14), Ahmed gomaa (2012) (5) where they argued that the use of technology methods help in the interaction of the teacher student with the application environment in a positive way, which creates the attention and excitement and helps him to perform the teaching competencies correctly and become more able to teach, in accordance with Ahmed Amin Fawzi (2006) (4) the symptoms of anxiety, which is the increase in the rate of breathing and heartbeat and pulse It has been reduced significantly.

As the researcher returns these results to the continued supervisor continuously with the teacher student is helped to overcome the difficulties in addition to reducing the feeling of fear and dread that may feel in the result of a mistake in the course of teaching that the electronic guidance has ended the situations that cause him fill in embarrassment Such as forgetfulness or stammering and the consideration of students and his colleagues in the case of his inability to complete the educational situation properly, which provided him with an educational environment helped him to reduce the anxiety of teaching during the teaching of sports education. 
IT has been achieved in the fourth hypothesis of the existence of statistical differences between the two post measurments of the test and control groups in the measurment scale of anxiety.

\section{Research conclusions}

Based on the results reached and associated with the research objectives and the methodology used and within the limits of the sample and its characteristics, the researcher reached the following conclusions

1. The electronic guidance device applied to the test group has a positive impact on the teaching competencies of the teacher student and is related to the implementation of the main part of the lesson of sports education.

2. The use of the electronic guidance system reduces and reduces the teaching anxiety of the teacher student .

3. Providing the student with the teacher feedback and correcting the error immediately and synchronously with the educational performance of each educational position contributed to the sufficient teaching required.

\section{Recommendations}

Based on the conclusions reached, the researcher recommends the following 1. Use the electronic guidance device to give students the field training nutrition feedback immediately to correct the teaching positions simultaneously with their performance to ensure the improvement of teaching competencies to them.

2. Adopting the concept of Tele Guide, developing it and using it to achieve the benefit of teaching and learning.

The researcher proposes the design of an electronic device for the development of teaching competencies for students of teachers in different educational materials.

\section{References}

I) Arabic References 
1 Abdel-Hamid 2007 : e-Learning and Mobile Education, Dar al-Kuttab Al-Alami, Bassiouni Cairo.

2 Abdullah

Saeed Mousi

Mohammed

3 Adnan

Darwish

2012 : The Effect of Both Electronic Communication and Mental Perspective on the Development of Some Instructional Skills for Internal Field Training Students", Dissertated Doctorate Thesis, Faculty of Physical Education for Boys, Alexandria University.

Jaloun

Ahmed Amin 2006 : Principles of Mathematical Psychology, Concepts, Fawzi

1998 : Physical Education and Sports School, Dar Al-Fikr Al-Arabi, Cairo.

2012 : training program based on e-learning to develop professional

Ahmed competencies and reduce the anxiety of teaching students in

Gomaa

Ahmed Arabic teachers College of Education, educational studies, Zagazig.

6

Ali Mohamed 2002 saleh

: Building a list of performance and professional competencies of kindergarten teachers associated with motor development, unpublished master thesis, Faculty of Physical Education, Helwan University

$7 \quad$ Ashraf

2008 : The impact of field training on the attitudes of students in the Mahmoud Al preparatory stage toward physical education, Master Thesis,

Shahat Faculty of Physical Education for Boys, Banha University

8 Bader

2005 : E-Learning and Instructional Design: A Partnership for Abdullah Quality, Research Presented to the 10th Conference of the Saleh

Egyptian Society for Educational Technology (E-Learning Technology and Total Quality Requirements), Cairo. 
9 Dina Ahmed 2008 : The Effect of a Proposed Program on the Use of UltraAl-Metwally Interference Media on the Level of Performance and Concern of Beginners in Dolphin Swimming, PhD Thesis, College of Sports Education

Mansoura University.

10 Eslam

Mohamed

salem
2007 : The Effect of Integrating Some Methods of Feedback in the Acquisition and Mastery of Exercises on the Achievement of Students in the Faculty of Physical Education, Unpublished Master Thesis, Faculty of Physical Education, Boys, Alexandria University, 2007.

11 Essam El Din 2006 : The Effect of an Educational Program Using Virtual Mohamed

Azmi,

Haitham

abdelmaged

mohamed

12

Fathi Youssef

Rachid

2002 : Evaluation of the performance competencies of the teacher of physical education in the first stage of main education in Alexandria, unpublished doctoral thesis, Faculty of Physical Education for Boys, Alexandria University.

13 Ghazi Ben 2010 : effective proposed training program based on active learning Salah strategies in the development of teaching skills among students of natural sciences, Umm Al-Qura University, the Board of Education,

14 Hazem

2010 : The influence of teaching in the method of cooperative Ahmed

Matroud, learning in reducing the level of anxiety in learning the skill of the memorable transmission of air ball, Rafidain magazine 
Waiting

for sports, C, 16, p53.

\section{Farouk Elias}

15 Hazem

Rashed

Ahmed

16 Heba Saeed 2009

Abdel-

Moneim
2007 : Program for the development of some of the skills of oral communication needed to teach and reduce concern among the female teachers, Journal of Reading and Knowledge, p.63

: Building an educational site and its impact on the acquisition of some teaching skills among students of practical education in the Teaching Department, Faculty of Physical Education in Tanta, Master Thesis, unpublished, Faculty of Physical Education, Tanta University

17 Huda Abdel 2000 : Impact of immediate and deferred feedback in learning some Samie Abdel

Wahab main skills of volleyball, Master Thesis, University of Baghdad, 2000.

18 Ibrahim 2002 :
Abdel-Wakil
Leading Research in Computer Education, Computer and El-Far Information Technology in Teaching and Learning, Faculty of Education, Tanta University, First Edition, June

19 Ismaiel 2005 : The Egyptian Society for Educational Technology, 10th Mohamed ismaiel Conference, Volume 15, Girls College, Ain Shams University.

20 Kamal Al - 2004 : Teaching teacher competencies in the planning of teaching Din Hashim the implementation of teaching - Evaluation in teaching, Al2006 Rashed Library, Riyadh.

21 Mahmoud 2006 : The dynamics of teaching physical education, I 1, the book Abdel Halim center for publishing, Assiut, 2006.
Abdel Karim

22 Marwan

2002 : Physical Growth and Dynamic Learning, International Abdel-Magid 
Ibrahim

23 Mohamed Hassan Allawi

24 Mohamed Saad Zaghloul 2001 : Educational technology and methods in sports education, book center, Cairo.

et al

25 Nahed Abdel - 2009 Rady Nubi
Distribution, Amman, Jordan, 1, 2002

2007 : Mathematical psychology, the tenth edition, Dar Knowledge, Cairo.
Effective program in the preparation of a physics teacher based on e - learning in the development of the knowledge component and skill decision - making towards e - learning among teacher students, the Council of Education, Egypt, Volume 12

26 Reem Nashid 2005 : Determination of the teaching competencies of the teacher Abdel Hamid: student in the subject field competitions and track College of Sports Education for Girls, a message Master, College of Education for Girls, Alexandria University.

27 Richard 2003 : guide to teaching sports education in schools, the series of Bailey the development of education, translation TIPTOP services for localization and translation, the Department of Educational Studies, Farouk Publishing and Distribution.

28 Samia

2002 : Teaching and training in physical education, Dar al-Hekma, Farghali Alexandria.

Mansour,Nadi

aMohamed

Abdelkader

29 Student

2002 : Effect of total and relative repetition with corrective feedback

Hussein in learning the main movements of free swimming, Master,

Hamza University of Babylon.

Masoudi 
30 Sulaiman bin 2007 : eacher and the entrance of competencies in teaching, Journal Saif Al- of Educational Development, Sultanate of Oman p 37

Ghunaimi

31 Waleed salem 2011 : E-Learning Innovative Applications, Arab Thought House, elhalafawy Cairo.

32 Yousef Diab 2010 : Active Learning Towards an Effective Educational Awad, Magdy Educational Philosophy Oman . Jordan

\section{Ali Zamil}

II) English references

33 Amr (2014) : The Impact Of A Cognitive Program Using Mobile Phone As Abdellah An External Feedback At The Cognitive Achievement Level Abdel And Skills Performance For Basketball

\section{Kader}

34 Williams, ;(1991) : "the Effects of a comprehensive teaching Assistant Training L.S. Program on teaching Anxiety and Effectiveness, Research in higher Education, vol.32, No.5, Oct 